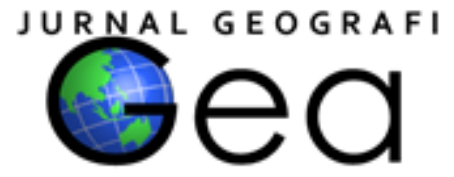

\title{
THE ROLE OF GEOGRAPHIC INFORMATION SCIENCE IN ACHIEVING SUSTAINABLE DEVELOPMENT GOALS (SDGs) DURING THE COVID-19 PANDEMIC
}

\author{
Annisa Joviani Astari' ${ }^{1}$, Assem Abdelmonem Ahmed Mohamed ${ }^{2}$, Riki Ridwana ${ }^{3}$ \\ 1,3 Geographic Information Science Study Program, Faculty of Social Science Education, \\ Universitas Pendidikan Indonesia \\ ${ }^{2}$ Agricultural Research Centre, Central Laboratory for Agricultural Climate, Egypt \\ 12annisa.astari@.upi.edu,2assem20000@yahoo.com,3rikiridwana@upi.edu
}

\begin{abstract}
Sustainable development and the goals that have been set by the UN are the results of mutual agreement on various pressing issues that must be addressed by our society. Along with the pandemic conditions that hit various parts of the world, the challenges for the realization of sustainable development are getting higher. Geospatial technology offers reliable tools to support the various processes and stages of planning, analysis, problem-solving, decision making, and process management necessary to pursue this common goal. GIScience has a very important role in investigating opportunities to help solve sustainable development problems. This study presents the state of the art of how GIScience plays a role to achieve sustainable development goals particularly during pandemic covid situations which result in a backward for some actors in several countries to achieve these goals. This study uses the content analysis method to analyze various issues related to sustainable development, SDGs, pandemic covid-19, and GIScience. Not only provide state of the art of research, but this paper also presents how GIScience can help to accelerate the problems thus the ultimate goal of sustainability can be achieved.
\end{abstract}

Keywords: Sustainable Development, SDGs, Pandemic, Covid-19, GIScience.

\section{INTRODUCTION}

The implementation of the Sustainable Development Goals (SDGs) has entered its 6th year since it was established in September 2015. The TPB/SDGs contain 17 goals and 169 targets for the 2015/2030 implementation period. The SDGs holistically accommodate various development pillars, not only economic and social pillars but also environmental pillars as well as law and governance. The SDGs targets and indicators have also been mapped into Indonesia's development roadmap, and the roadmap can be used as the basis for prioritizing each strategy to be implemented.

With the Covid 19 pandemic starting to be felt by the global community at the end of 2019, this will certainly affect various global and national development schemes. There is a report which reveals that the achievement of SDGs by 2030 for all countries in the world are off-track, thus the need to do a collective action i.e., the cooperation between countries in the world is urgently needed to make significant progress for these SDGs implementations (Runde et al., 2020; Sachs et al., 2019).

Before the current global pandemic, the financing gap to achieve the SDGs by 2030 was estimated at US\$2.5 trillion per year. Most of this financing is expected to come from developing country government revenues and savings, which could be increased through simultaneous domestic resource mobilization efforts on a global scale (Heggen et al., 2020; Runde et al., 2020). The global recession caused by the COVID-19 response is worrying and has led researchers to question whether the sustainable development goals (SDGs) are appropriate for post-pandemic situations (Nature, 2020). The current resources will certainly be prioritized for handling the COVID-19 pandemic, and also supporting the 
economy of the people who have been affected a lot. The COVID-19 pandemic is also expected to affect the overall target for achieving the SDGs (The Lancet Public Health, 2020).

Global cooperation and scientific approaches that are multi-disciplinary are urgently needed during the pandemic and also post-pandemic to achieve sustainable development targets. The latest report from Elsevier (2020) shows how the power of data in mapping various studies in helping decisionmakers to achieve sustainable development. In this case, geographic information science is also one of the sciences that can contribute greatly in providing data for stakeholder analysis at the local, national and global levels and from various sectors ranging from health, education, poverty, agriculture, forestry, and other vital sectors.

This paper will discuss more deeply the challenges and roles of geographic information science and its various approaches to help achieve the SDGs during the Covid-19 pandemic and also post-pandemic. This paper will begin with a theoretical review of various literature related to Covid-19 and the Sustainable Development Goals (SDGs), then continue with a discussion of the role of SaIG in achieving the SDGs in the pandemic era.

\section{LITERATURE REVIEW \\ Covid-19 Pandemic}

Coronavirus is one of the main pathogens that attack the human respiratory system (Rothan \& Byrareddy, 2020). Previous outbreaks of Coronavirus (CoV) including severe acute respiratory syndrome (SARS)$\mathrm{CoV}$ and the Middle East respiratory syndrome (MERS)-CoV have previously been characterized as agents that pose a major public health threat (Rothan \& Byrareddy, 2020). The emergence of Covid-19 started from a seafood and animal market in Wuhan City, Hubei Province, China (Bogoch et al., 2020). The chronology of Covid-19 infection is from the first five victims who were hospitalized patients with acute respiratory distress syndrome and one of the patients died. The disease then spread to various medical personnel devices until on January 2, 2020, 41 hospital patients who were treated at the same hospital were identified as having Covid-19 infection (Ibid).

\section{Sustainable Development Goals}

Sustainable development is a principle and goal that has been intensively discussed by stakeholders in various sectors at the local, national and global levels. The publication of Our Common Future 'issued by the World Commission on Environment and Development (WCED) in 1987 is the basis of the conceptualization of sustainable development which emphasizes that in a development process one must ensure that the needs of the present are met without compromising the interests of future generations to meet their own needs. their own needs (WCED, 1987). Environmental and social problems as a result of development have always been a concern for the global community and this must be a common concern for all parties around the world. As a more practical effort to achieve the implementation of the vision of sustainability, the United Nations (UN) set the Millennium Development Goals (MDGs) which were set in 2000-2015. The MDGs guide the global development agenda over the period 20002015, and consist of eight goals, ranging from eradicating poverty and hunger to ensuring environmental sustainability, with measurable and time-bound goals. The MDGs framework has been used successfully in achieving sustainable development targets in several countries, for example halving poverty, reducing maternal and child mortality in childbirth (Reed et al., 2015). After the 15 years of implementing the MDGs is complete, and then the Sustainable Development Goals (SDGs) Agenda is set on September 25, 2015, at the United Nations (UN) Headquarters. Approximately 193 heads of state attended, including Indonesian Vice President Jusuf Kalla who also endorsed the SDGs Agenda. The SDGs framework consists of 17 Goals (Table 1) and 169 Targets which are global action plans that are valid from 2016 to 2030 (15 years). The SDGs aim to end poverty, reduce inequality and protect the environment. The SDGs are universally applied to all countries in the world, or in other words that 
all countries, both developed and developing countries, have a moral obligation to achieve the goals and targets of the SDGs that have been set.

\section{SDGs Implementation in Indonesia}

As a form of the government's political commitment to implement the SDGs, President Jokowi has signed the Presidential Regulation (Perpres) on SDGs Number 59 of 2017 concerning the Implementation of achieving Sustainable Development Goals.

The Presidential Regulation is also a commitment so that the implementation and achievement of the SDGs are carried out in a participatory manner by involving all parties. Indonesia's efforts to implement the SDGs agenda are built on experience from the past implementation of the Millennium Development Goals (MDGs) agenda. During the 15 years of implementing the MDGs, Indonesia has succeeded in achieving 49 of the 67 indicator targets set. For the SDGs, of the 169 global targets, 94 targets have been integrated into the 2015-2019 RPJMN, and 123 targets have been integrated into the 20202024 RPJMN (Kementerian PPN/Bappenas, 2018).

The targets in the SDGs raise concerns from various parties both about how these 17 goals and targets can be linked to each other and how to implement them so that these goals can be achieved. This is a concern from various parties considering that Indonesia is a large country consisting of various islands and also hundreds of cultural tribes. It is undeniable that the implementation of the SDGs requires systematic policy design, comprehensive implementation strategies, and collaboration from various stakeholders. All of these global development goals and targets must be properly translated so that they can produce concrete results on the ground. The linkages of the SDGs targets and indicators have also been mapped into Indonesia's development roadmap, and this roadmap can be used as the basis for prioritizing each strategy to be implemented. Based on the studies that have been carried out, by meeting certain SDG targets, we can increase the achievement of other SDG targets as well (Kementerian PPN/Bappenas, 2018; X. Zhou \& Moinuddin,
2017). Because of this, all the targets and indicators of the SDGs cannot be considered as a separate component but must be seen as a unit with other targets to form a comprehensive framework Geographic Information Science (Kementerian PPN/Bappenas, 2018).

\section{Geographic Information Science}

Geographic Information Science catalyzes knowledge and spatial methodologies from geography, cartography, remote sensing, landscape architecture, landscape ecology, urban planning, geodetic and surveying science, computer science, civil engineering and environmental sciences, cognitive science, behavioural sciences, science and technology, decisions, network science, and many other disciplines. Its broad intellectual foundation results in diverse economic, social, and ecological applications. GIScience is in the right position to be positioned in overcoming various social challenges and targets summarized in the SDGs (Yuan, 2021).

\section{RESEARCH METHOD}

This study uses qualitative content analysis by examining secondary data searches such as policy documents, articles, and research reports regarding the roles of geographic information science for achieving SDGs during pandemic Covid 19. We use NVIVO software to do the theme coding. The papers that have been documented are only from 2020 until 2021 which will represent the state of the art of academic research related to the achievement of SDGs and pandemic Covid 19. Keywords such as sustainable development, SDGs, pandemic Covid 19, GIScience, GIS, and remote sensing, cartography were the main keywords in identifying the papers.

\section{RESULTS AND DISCUSSION Examples of GIScience Role in Achieving SDGs in a Pandemic Situation}

It is undeniable that the COVID-19 pandemic has hampered the achievement of sustainable development goals. It can be seen from Figure 2 below how the Covid 19 pandemic affects the 17 goals set as sustainable development. For example, from SDG 1, there 
will be several layers of society that are vulnerable to losing sources of income and this will trigger an increase in the number of community members or families who are below the poverty line. SDG 4 illustrates that because many schools are closed, although distance learning is carried out, the learning is less effective and not all levels of society have equal access to online education, the quality of education will also affect development goals. The effects of the Covid 19 pandemic on the implementation of SDGs has been published by the United Nation Sustainable Development Group and can be seen in Figure 1.

There are plenty of data regarding this pandemic. With about a million different data sources out there for coronavirus information, as well as its impact on different sectors, experts, governments, and various authorities need to provide the public with useful information. Many questions arises including:

- Does the death toll continue to rise sharply?

- Is the curve flattening?

- How does the virus move, and how do you prevent it?

- How to decide to eradicate poverty by targeting the most affected areas (which is also in line with SDG1)?

To compile all this information, Geographic Information System (GIS) software is needed. GIS advances the process of discovering and communicating that knowledge, giving rise to complex and dynamic factors that influence our perception and cognition of things and events in geographic space, and determine their spatial effects and consequences on prediction and decision making. In achieving the SDGs targets, GIS is used in processing, data hosting, data sharing, imaging processing, simulation, and decision making in infrastructure improvement priorities.

Some of the maps presented in this paper show the role of GIS in mapping the condition of COVID 19 and also include some data that also supports the achievement of the SDGs. Figure 2 (a) presents a mapping carried out by the Center for Systems Science and Engineering (CSSE) at Johns Hopkins University. Mapping of the global COVID-19 pandemic is shown by displaying the number of cases by country or region. Another data also presents the unemployment data in the United States which is mapped using the Geographic Information System (GIS). It can be seen from the map that there are several countries whose unemployment rates have increased, as well as decreased, and the numbers vary. This mapping will greatly help decision-makers to be able to see which areas are most economically affected during this pandemic and to stay in line with sustainable development targets, especially SDG1 related to poverty and SDG 8 regarding economic growth and employment, so the decisions taken will also affect the achievement of these goals.

For the national and regional levels, the government has also created several data platforms, especially about the number of patients, suspects, and also close contacts. Figure 4 shows a map of regional vulnerability due to Covid 19 on the first high school in the city of Bandung. This will help the government to determine the stages of opening schools offline with strict health protocols. Schools located in clusters or areas with low vulnerability levels can begin to gradually open their schools, while areas with high vulnerability levels cannot yet carry out offline learning (Figure 2 (b)).

\section{State of the Art of Research in SDGs Studies During a Pandemic Situation.}

Several studies have been conducted linking synergies as well as trade-offs between the SDGs and their various interactions. Various issues are also the subject of study from these studies, starting from local and global scales. Some papers focus on several SDGs and some papers only focus on one SDGs, for example SDGs 4 (Chabbott \& Sinclair, 2020).

Most of the use of GIS during the COVID-19 pandemic is related to distribution patterns and the number of confirmed cases, which is very relevant to urban planning and health policy-making which is also the focus of the SDGs. Papers from Zhou et al. (2020) explain that there is a need for integration from traditional data into big data from various existing organizations. Through an innovative construction technology system, this study 
provides a technical platform for timely epidemic analysis. Bherwani et.al., (2021) conducted a study on air quality from several areas in India using GIS to find out how the relationship between the COVID-19 pandemic conditions and air quality in those areas.

There is one interesting thing, namely the paper from Fisher (2020) and Filho et al (2020) which stated that the COVID pandemic caused the SDGs to be out of reach. In terms of education, the article written by Iyengar (2020) emphasizes that the existing education system must recognize how technology and community-driven systems can help students and students learn.

\section{The Role of GIScience for the Achievement of SDGs During a Pandemic}

Several spatial approaches and using geographic information science can be utilized to achieve the SDGs during the current COVID-19 pandemic. The first approach is trend mapping. By mapping trends about many main aspects of the Covid-19 pandemic, for example, cases spreading and surging, and so on. The map helps to give focus to decisionmakers on which areas are priority areas, or for example in education aspects which areas can already implement activities within the 'new normal' framework.

The next approach is to maintain the resiliency or resilience of the community and organization. Contact tracing and community interaction are some of the efforts that can be done to maintain community resilience (SDG 16) through GIS so that the required health capacity (SDG 3), food distribution and business distribution, and so on can be monitored properly. Mapping organizational resilience is especially important during a pandemic to support SDGs 2, 8, 17.

Impact mapping is an important aspect of the spatial approach. The map-based app helps leaders quickly assess the impact of the COVID-19 crisis. With unemployment soaring, the map displays economic vulnerabilities in various locations. Leaders from business and government can understand the impact on revenues and budgets to respond and plan.

Various aspects can use maps to communicate something to the public. The use of a spatial approach to achieve the goals of the SDGs both during the pandemic and postpandemic will help to build back better the situation and achievement of various sustainable development goals and vision.

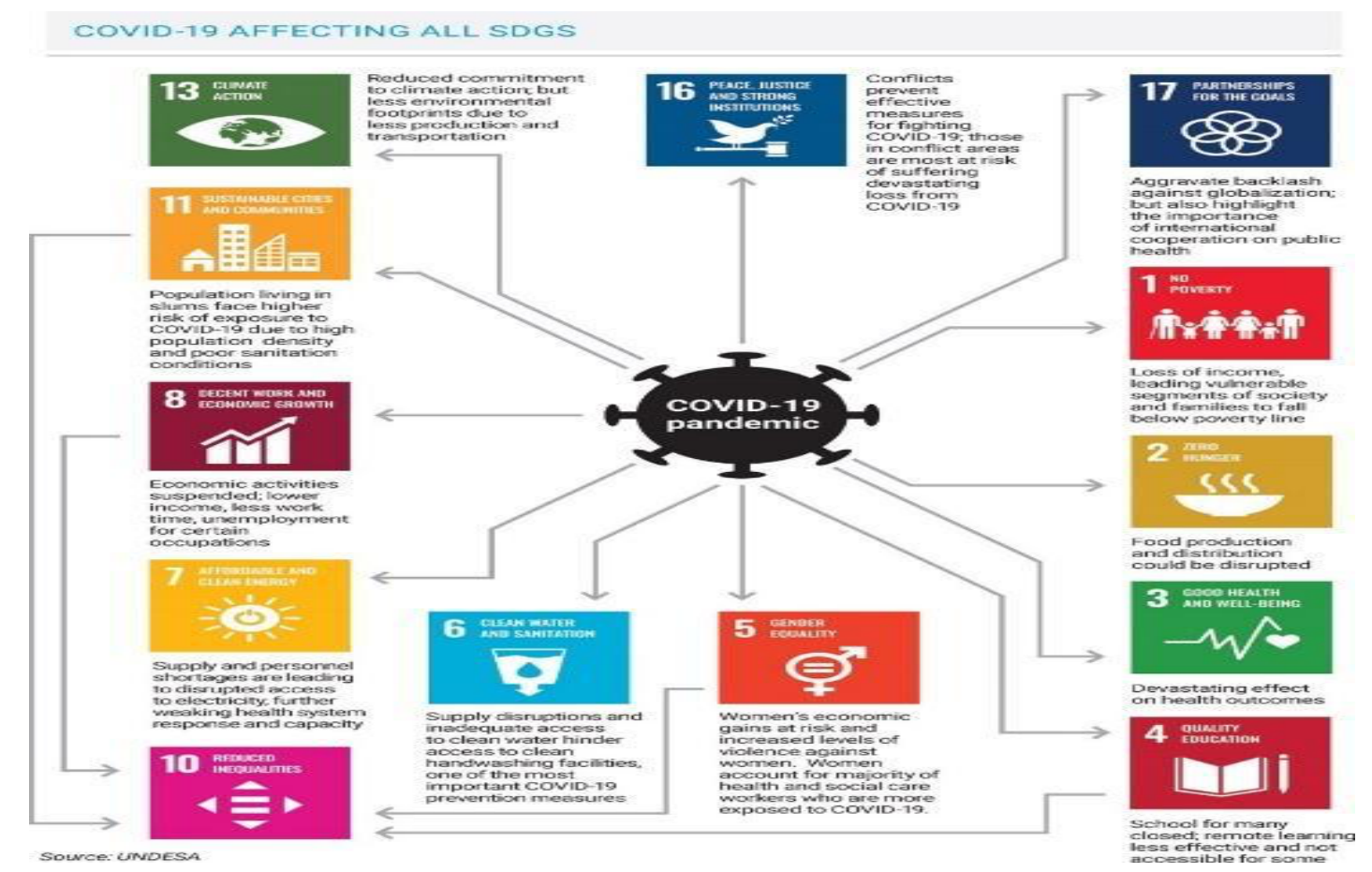

Figure 1. The effects of the Covid 19 pandemic on the implementation of Sustainable Development Goals (United Nation Sustainable Development Group, 2020 


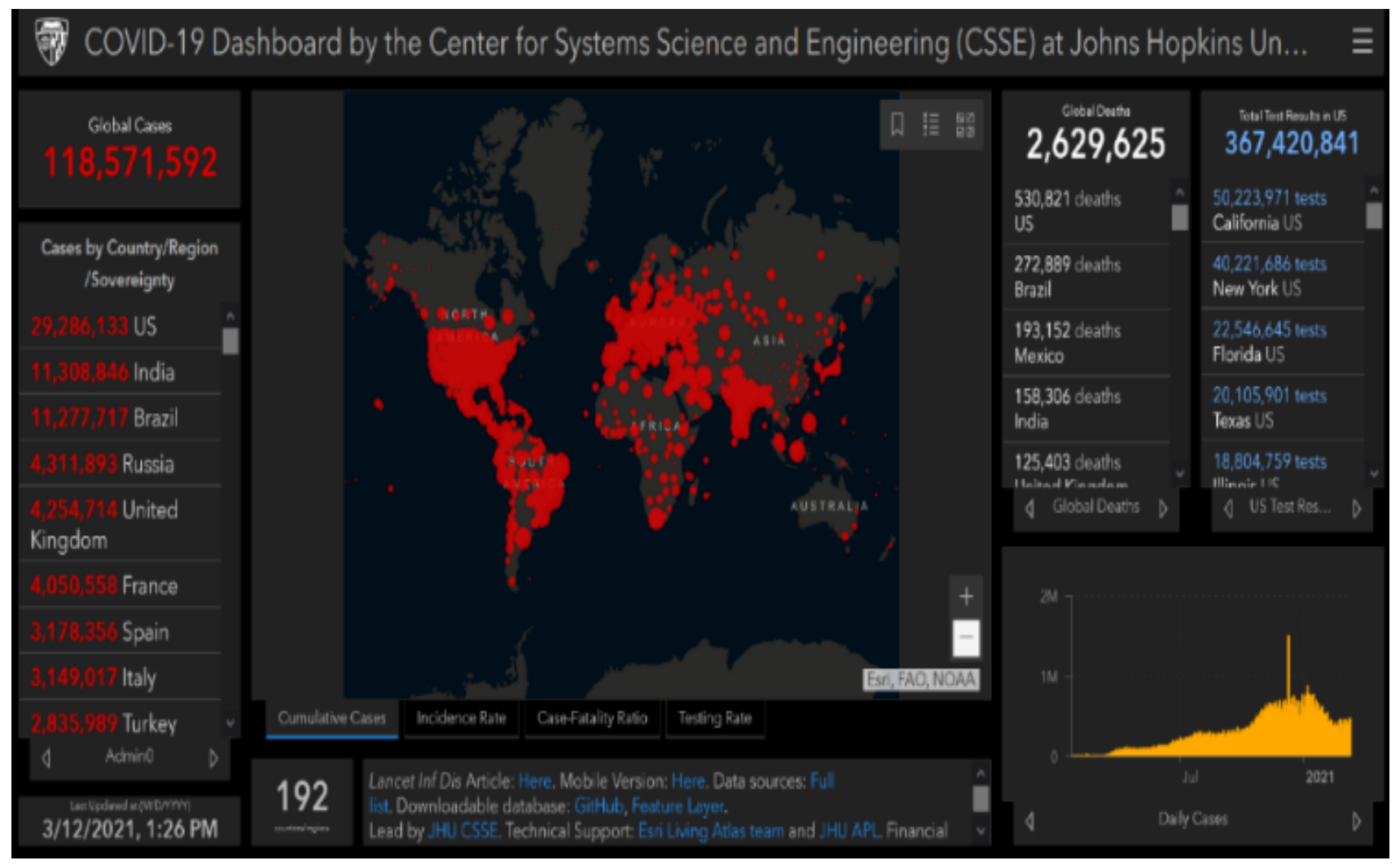

Figure 2. (a) Mapping global pandemic by the Center for Systems Science and Engineering (CSSE), Johns Hopkins University (Esri, 2021a)

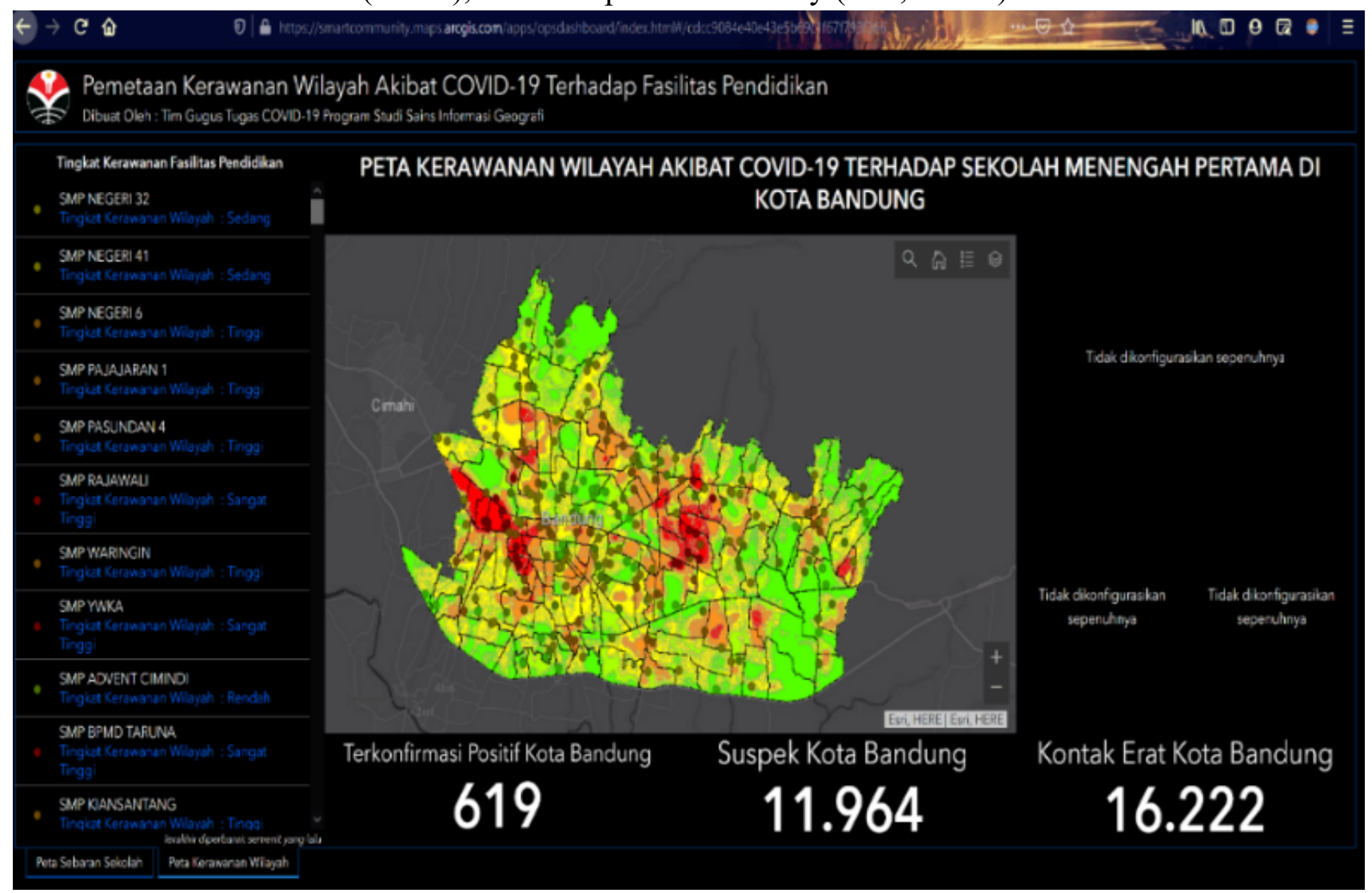

Figure 2. (b) The Results of Processing the Map at the Level of Vulnerability Zones for Junior High Schools

(Source: GIScience Study Program, Universitas Pendidikan Indonesia, 2021) 


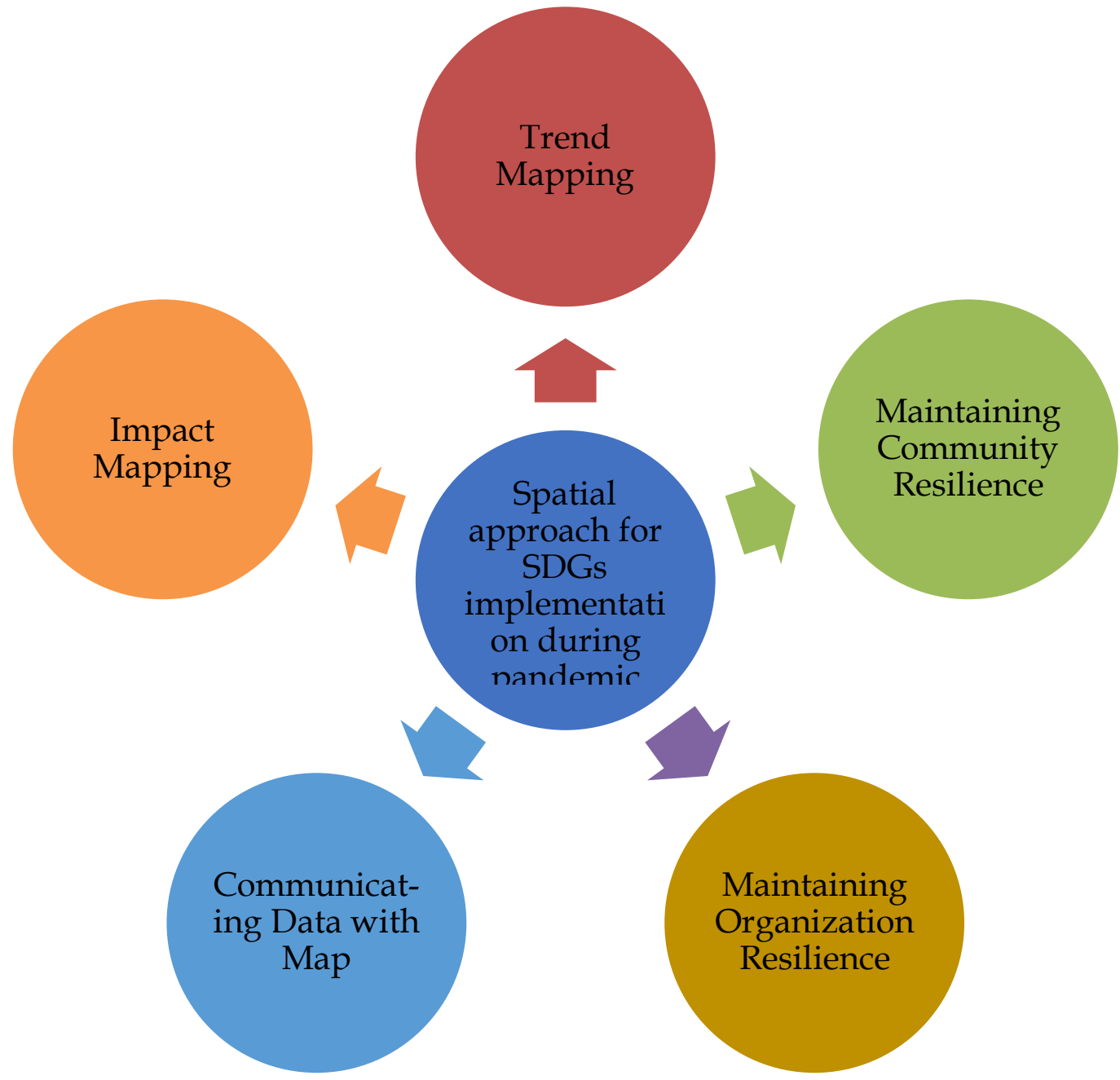

Figure 3. Spatial Approach for SDGs Implementation During a Pandemic

Table 1. Recent Studies (2020-2021) on SDGs, COVID-19, and the Role of GIScience

\begin{tabular}{|c|c|c|c|c|}
\hline No. & Title of Paper & Year & Authors & $\begin{array}{c}\text { A Key Point for SDGs, } \\
\text { Covid-19, and the Role } \\
\text { of GIScience }\end{array}$ \\
\hline 1 & $\begin{array}{l}\text { A Participatory Geospatial } \\
\text { Toolkit for Science Integration } \\
\text { and Knowledge Transfer } \\
\text { Informing SDGs Based } \\
\text { Governance and Decision Making }\end{array}$ & 2020 & $\begin{array}{c}\text { (Sajeva et al., } \\
\text { 2020) }\end{array}$ & $\begin{array}{l}\text { This paper presents a } \\
\text { participatory geospatial } \\
\text { toolkit developed during } \\
\text { the BONUS MARES } \\
\text { project that enables } \\
\text { science integration and } \\
\text { knowledge transfer } \\
\text { informing SDGs based } \\
\text { governance and decision } \\
\text { making. }\end{array}$ \\
\hline 2 & $\begin{array}{l}\text { Analyzing interactions among the } \\
\text { sustainable development goals: } \\
\text { findings and emerging issues } \\
\text { from local and global studies }\end{array}$ & 2020 & $\begin{array}{c}\text { (Alcamo et al., } \\
2020 \text { ) }\end{array}$ & $\begin{array}{l}\text { This paper focuses on } \\
\text { interactions } \\
\text { among the SDGs, in } \\
\text { particular trade-offs and } \\
\text { synergies. }\end{array}$ \\
\hline
\end{tabular}


The Power of Data to Advance the SDGs Contents

2020

RELX Group

This paper provides research data through a map to address existing gaps and further progress towards SDGs.

This paper highlights opportunities for

Geographical information science

4 for the United Nations' 2030 agenda for sustainable

$2021 \quad$ (Yuan, 2021) development
GIScience contributions and challenges to the UN SDGs.
Putting the UN SDGs on the

5 Map: The Role of Cartography in Sustainability Education
2020

(Kent et al., 2020)
This paper preview various research published in The Cartographic Journal, therefore, highlights the important role that cartography plays in meeting the SDGs.
SDG 4 and the COVID-19

6 emergency: Textbooks, tutoring, and teachers
2020

\section{$\underline{-}$}

Spatial analysis of COVID-19 and inequalities in Mexico City
(RodríguezIzquierdo et al., 2020)

This paper highlights SDG 4 and presents the key to preparing better for the next crisis.

This paper presents a descriptive, spatial study of the distribution of the COVID-19 and how its impacting water availability and also household overcrowding. The result is relevant for urban planning, health policymaking, which are parts of the SGDs.

This paper advances ten propositions that will shape policy dialogue and

Contingent reflections on 8 coronavirus and priorities for educational planning and development
$2020 \quad$ (Lewin, 2020) whatever iteration of the Sustainable Development Goals is needed to ensure they remain fit for purpose.

From fighting COVID-19 9 pandemic to tackling sustainable development goals: An opportunity for responsible information systems research
(Pan \& Zhang, 2020)
This article highlights the six relevant themes that have evolved during the pandemic and the corresponding topics that future researchers could focus on.

The article contributes to

(Krellenberg \& the discussion on the

10 between SDGs and Urban 2021 Koch, 2021) Covid-19 Times implementing SDGs in 
cities and presents some solutions for Urban

Sustainability

Transformations.

\begin{tabular}{|c|c|c|c|c|}
\hline 11 & $\begin{array}{l}\text { Education as the path to a } \\
\text { sustainable recovery from } \\
\text { COVID-19 }\end{array}$ & 2020 & (Iyengar, 2020) & $\begin{array}{l}\text { The article argues that } \\
\text { post-COVID-19, } \\
\text { education systems should } \\
\text { recognize community- } \\
\text { driven support systems, } \\
\text { use technology to } \\
\text { overcome the digital } \\
\text { divide in learning, and } \\
\text { focus more on SDG } 4.7 \text {. }\end{array}$ \\
\hline 12 & $\begin{array}{l}\text { " Digital Health Earth ": towards } \\
\text { global healthcare management } \\
\text { geolocating human health } \\
\text { condition by means of space } \\
\text { technology }\end{array}$ & 2021 & $\begin{array}{l}\text { (Del Mastro et } \\
\text { al., 2021) }\end{array}$ & $\begin{array}{l}\text { This paper provides data } \\
\text { and reports about } \\
\text { healthcare statistics and } \\
\text { risk management around } \\
\text { the world benefit } \\
\text { from Digital Earth Project } \\
\text { and real-time dashboard. }\end{array}$ \\
\hline 13 & $\begin{array}{l}\text { COVID-19: Challenges to GIS } \\
\text { with Big Data }\end{array}$ & 2020 & $\begin{array}{l}\text { (C. Zhou et al., } \\
\text { 2020) }\end{array}$ & $\begin{array}{l}\text { This study encounters the } \\
\text { data acquisition methods } \\
\text { through big data } \\
\text { technology, which } \\
\text { achieved rapid data } \\
\text { acquisition and } \\
\text { integration. }\end{array}$ \\
\hline 14 & $\begin{array}{l}\text { Qualitative and quantitative } \\
\text { analyses of impact of COVID - } \\
19 \text { on sustainable development } \\
\text { goals (SDGs) in Indian } \\
\text { subcontinent with a focus on air } \\
\text { quality }\end{array}$ & 2021 & $\begin{array}{l}\text { Bherwani, H } \\
\text { Gupta, S } \\
\text { Gautam A }\end{array}$ & $\begin{array}{l}\text { This study identifies the } \\
\text { air quality in the region } \\
\text { and its relation with } \\
\text { COVID-19-affected } \\
\text { people in metropolitan } \\
\text { cities of India during } \\
\text { COVID-19 lockdowns } \\
\text { using a GIS using ArcMap } \\
\text { (Thiessen polygons). }\end{array}$ \\
\hline
\end{tabular}

\section{CONCLUSIONS}

The Covid 19 pandemic, which has affected all countries in the world, however, will have an impact on various development schemes that have been set by the government and various stakeholders, both nationally and globally. The sustainable development goals or SDGs will also be affected because the existing resources will be prioritized in handling the Covid 19 pandemic. However, efforts to handle the Covid 19 pandemic should be aligned with the various existing development goals. Geographic information science with a geospatial approach can be used to map various information and impacts for the recovery of public health, the economy, and various other sectors that are affected. With various mappings that have been carried out, approaches that can be used include trend mapping, mapping to maintain community or community resilience and organizations, impact mapping, and communicating data with maps. The geospatial approach can continue to be carried out for the achievement of 17 sustainable development goals during and after the pandemic, awareness focused on the power of geographic thinking will be very important to keep communities safe and healthy so that 
sustainable development goals and targets will be achieved.

\section{RECOMMENDATIONS}

Some important points that need to be pointed out regarding the role of geospatial data and information to achieve SDGs particularly during pandemic situations are including that geospatial data and information must be integrated with non-spatial data and information. In principle, as geospatial data will provide a base as raw data for creating useful information, it will then become useful knowledge and wisdom which is important for the decision-making process. Geospatial information is an important tool for integration and coordination. There are some indicators for all goals, from global, national, and local regarding the SDGs. The geospatial data and information can be a hub to integrate data between all levels and sectors. Most importantly, collaborating with stakeholders is the KEY to achieve the SDGs using geospatial information. As we know that specialist often has deep knowledge regarding their field but collaborating with other stakeholders need a common agreed knowledge between several specialists, thus a conflict of interest is also an issue that needs to be solved for the step toward SDGs 2030 achievements.

\section{REFERENCES}

Alcamo, J., Thompson, J., Alexander, A., Antoniades, A., Delabre, I., Dolley, J., Marshall, F., Menton, M., Middleton, J., \& Scharlemann, J. P. W. (2020). Analyzing interactions among the sustainable development goals: findings and emerging issues from local and global studies. Sustainability Science, 15(6), 1561-1572. https://doi.org/10.1007/s11625-020-00875$\mathrm{x}$

Bogoch, I. I., Watts, A., Thomas-Bachl, A., Huber, C., Kraemer, M. U. G., \& Khan, K. (2020). Pneumonia of unknown aetiology in Wuhan, China: potential for international spread via commercial air travel. Journal of Travel Medicine, 27(2), 7.

Chabbott, C., \& Sinclair, M. (2020). SDG 4 and the COVID-19 emergency: Textbooks, tutoring, and teachers. Prospects, 49(1-2), 51-57. https://doi.org/10.1007/s11125- 020-09485-y

Del Mastro, A., Federico, M., Eremchenko, E., \& Nelson, B. (2021). "Digital Health Earth": towards global healthcare management geolocating human health conditions by means of space technology. Geocontext, $8, \quad 52-71$. https://doi.org/10.30987/2686-8326-202152-71

Heggen, K., Sandset, T. J., \& Engebresten, E. (2020). COVID-19 and sustainable development. International Journal of Sustainable Development, 23(1-2), 1-24. https://doi.org/10.1504/IJSD.2020.112182

Iyengar, R. (2020). Education as the path to a sustainable recovery from COVID- 19. Prospects, 49(1-2), 77-80. https://doi.org/10.1007/s11125-020-094889

Kementerian PPN/Bappenas. (2018). Roadmap of SDGs Indonesia Towards 2030. http://sdgsindonesia.or.id/\%0Ahttps://drive .google.com/file/d/1SnQY_t52KZaEVub8 U6JEh1rSL BhrY3b/view

Kent, A. J., Vujakovic, P., Eades, G., \& Davis, M. (2020). Putting the UN SDGs on the Map: The Role of Cartography in Sustainability Education. Cartographic Journal, 57(2), 93-96. https://doi.org/10.1080/00087041.2020.17 70424

Krellenberg, K., \& Koch, F. (2021). Conceptualizing Interactions between SDGs and Urban Sustainability Transformations in Covid-19 Times. 9(1), 200-210.

https://doi.org/10.17645/pag.v9i1.3607

Lewin, K. M. (2020). Contingent reflections on coronavirus and priorities for educational planning and development. Prospects, 49(1-2), 17-24. https://doi.org/10.1007/s11125-020-094803

Nature. (2020). Time to revise the Sustainable Development Goals. Nature, 583(7816), 331-332. https://doi.org/10.1038/d41586020-02002-3

Pan, S. L., \& Zhang, S. (2020). From fighting COVID-19 pandemic to tackling sustainable development goals: An 
opportunity for responsible information systems research. International Journal of Information Management, 55(January), 16.

Rodríguez-Izquierdo, E., Pérez-Jimenez, S., Merino-Pérez, L., \& Mazari-Hiriart, M. (2020). Spatial analysis of COVID-19 and inequalities in Mexico City. Analisis Pendapatan Dan Tingkat Kesejahteraan Rumah Tangga Petani, 53(June), 16891699.

Rothan, H. A., \& Byrareddy, S. N. (2020). The epidemiology and pathogenesis of coronavirus disease (COVID-19) outbreak. Journal of Autoimmunity, 109(February), 102433.

https://doi.org/10.1016/j.jaut.2020.102433

Runde, B. D. F., Metzger, C., \& Abdullah, H. F. (2020). Covid-19 Demands Innovative Ideas for Financing the SDGs. Center for Strategic \& International Studies, May, 111.

Sachs, J., Schmidt-Traub, G., Kroll, C., Lafortune, G., \& Fuller, G. (2019). Sustainable Development Report 2019.

Sajeva, M., Maidell, M., \& Kotta, J. (2020). A participatory geospatial toolkit for science integration and knowledge transfer informing SDGs based governance and decision making. Sustainability (Switzerland), 12(19), 1-19. https://doi.org/10.3390/su12198088
The Lancet Public Health. (2020). Will the COVID-19 pandemic threaten the SDGs? The Lancet Public Health, 5(9), e460. https://doi.org/10.1016/S24682667(20)30189-4

WCED. (1987). Report of the World Commission on Environment and Development: Our Common Future.

Yuan, M. (2021). Geographical information science for the United Nations' 2030 agenda for sustainable development. International Journal of Geographical Information Science, 35(1), 1-8. https://doi.org/10.1080/13658816.2020.17 66244

Zhou, C., Su, F., Pei, T., Zhang, A., Du, Y., Luo, B., Cao, Z., Wang, J., Yuan, W., Zhu, Y., Song, C., Chen, J., Xu, J., Li, F., Ma, T., Jiang, L., Yan, F., Yi, J., Hu, Y., ... Xiao, H. (2020). COVID-19: Challenges to GIS with Big Data. Geography and Sustainability, 1(1), 77-87. https://doi.org/10.1016/j.geosus.2020.03.0 05

Zhou, X., \& Moinuddin, M. (2017). Sustainable Development Goals Interlinkages and Network Analysis: A practical tool for SDG integration and policy coherence. The Institute for Global Environmental Strategies (IGES), June, 140. https://doi.org/10.1128/MCB.0546011 